\title{
Religion as Mediation
}

\author{
BIRGIT MEYER \\ Utrecht University, Netherlands
}

\begin{abstract}
Why and how is it productive to conceptualize religion as mediation? In this article, I 1) rehearse the intellectual trajectory of the move from studying the implications of the adoption of new mass media into religious practices to a broader idea of religion as a practice of mediation; 2) address some criticisms raised with regard to the concept of religion-as-mediation from my position in the interface of anthropology and religious studies; 3 ) discuss the evocation of a sense of transcendence through sensational forms, and, 4) by way of an outlook, pinpoint how conceptualizing religion as mediation is useful to unpack religious plurality.
\end{abstract}

KEYWORDS media, mediation, sensational form, immanent and transcendent, plurality

\section{Introduction}

There is a broad agreement among scholars in the study of religion that definitions of religion are shaped by and authorized within specific, historically situated modern Western discursive contexts and power structures (e.g. Asad 1993; Dubuisson 2003; Chidester 2014; see also Kippenberg 1997, 259-70). This has enhanced our awareness of the extent to which supposedly neutral definitions are inflected with post-enlightenment Protestant and by now secularized viewpoints (e.g. Asad 1993, 27-54; Keane 2007). The fact that the term religion, in the slipstream of colonization and missionization, gained currency across the world through multiple, albeit imperfect translations that were propelled back into the academic study of religion (Chidester 2014, 2018, 122; see also Hermann 2015) cautions against its unproblematic use. ${ }^{1}$ Defining religion has become highly contested-for good reasons.

And yet, scholars-whether in the framework of religious studies or the anthropology and

$1 \quad$ This has been a major theme in anthropological research tracing the effects and impacts of the export of missionary Christianity into spheres of Western imperial outreach (e.g. Comaroff and Comaroff 1992, 1997). My own work is grounded in the realization that religion and associated terms failed to capture the complexity of indigenous practices of the Ewe (among whom I conducted ethnographic research in the late 1980s and early 1990s) of speaking about and relating to spirits and gods. As many other anthropologists undergoing similar experiences, since that time I have been sensitive to the vicissitudes of translation. For a recent reflection in the light of Chidester's notion of the "frontier zone," see Meyer (2018). 
sociology of religion-obviously cannot afford to let go of the term religion, if only because it designates the subject matter of their inquiries and brings them together. As definitions are not necessarily spelled out, but nonetheless underpin the use of methods and theories in an implicit manner, a declared rejection of the use of definitions will not do. One welcome effect of the debate about the definability of religion is that it serves as a platform for its participants to assess whether they are talking about the same thing (Stausberg 2012, 38). I think that besides finding out to what extent they do so, there also is a need for pro-active and pragmatic interventions in which scholars spell out what they mean by religion, with the aim to pinpoint new conceptual and methodological directions for research and debate. This echoes the declared aim of the platform Entangled Religions to engage with "explicit analytical concepts" which can serve as tertia comparationis. Obviously, there are numerous possibilities to conceptualize religion - or dimensions thereof-that are not necessarily mutually exclusive, each having the potential to generate insights. My plea to approach religion as mediation, which I take as a productive tertium, is situated against this backdrop.

I hasten to assert that, rather than searching for a 'real definition' (Realdefinition) of religion as an essence that has an ontological existence across the world, I employ 'religion' as a generalizing concept through which certain practices, ideas and things-e.g. with regard to the mediation of a sense of a 'beyond' - can be grouped and compared. Echoing a nominalist stance towards definition in the footsteps of Wittgenstein's idea of family resemblances (2001, 27-28, No 67), such a conceptualization is situated in a broader epistemological endeavour in which scholars take their concepts and the phenomena to which they refer as neither totally congruent with nor totally independent from each other. The reason why I prefer to talk about concepts rather than definitions is that the latter tend to be more strongly associated with positivistic forms of knowledge production, for which fixed definitions form the starting point, whereas concepts are more open and subject to refinement and revision in the process of empirical research. The point here is a balancing act, in which concepts are made to capturein the sense of begreifen - a particular phenomenon and yet are not limited to it (and vice versa) (Vries 2008, 5; see also Meyer 2015a, 336-37). The critical analytical value of a concept lies in its sensitizing capacity and thus "the extent to which it allows us to unlock and throw light on not so obvious aspects of a world of lived experience-looking deep-and to allow for comparison-looking across" (Meyer 2016, 13). From such a vantage point, scholarship can be taken as a space for critical reflexion about the (un)productivity of concepts to gain insights into certain phenomena that can be grouped as 'religion' or qualified as 'religious' due to sharing certain (though not necessarily all) typical features.

In this article, I want to discuss why and how it is productive to conceptualize religion as mediation. I will 1) rehearse the intellectual trajectory of the move from studying the implications of the adoption of new mass media into religious practices to a broader idea of religion as practice of mediation between the immanent and transcendent, through which the latter becomes real and tangible in the former for those engaging in this practice; 2) address some criticisms raised with regard to my coinage of religion-as-mediation; 3) discuss the evocation of a sense of transcendence through sensational forms, and, 4) by way of an outlook, pinpoint how conceptualizing religion as mediation is useful to unpack religious plurality. Throughout I will pay attention to issues of authority and authorization, on which any possibility for collectively shared, binding mediations, as we encounter them in religious traditions (and in practices of binding and gathering at large), depends. 


\section{Media-Mediation}

The push to engage in conceptual reflexion comes with collaborative research. I started to think about religion as mediation in the context of a joint anthropological research project on religion, modern mass media, and the imagination of communities directed by me at the University of Amsterdam (2000-2006). ${ }^{2}$ Studying the negotiation and incorporation of newly accessible electronic mass media-at the time these were above all radio, television, and video, and only to some extent digital ('social') media-in various religious settings in Africa, Brazil, South Asia, and the Caribbean required an overarching conceptual framework so as to connect and talk across the various researches (Meyer 2009). Initially, our main interest concerned the role of such electronic mass media in bringing about new "imagined communities" (Anderson 1991) that were grounded in religious viewpoints and became manifest in the public domain as a result of mass media deregulation undertaken by hitherto authoritarian states, on the one hand, and the easy accessibility of electronic (and later on digital) media technologies, on the other. So we understood such media as means for assembling people as religious (counter)publics. Ethnographic research demonstrated that the adoption of new media into religious groups was carefully negotiated in the light of existing (explicit and implicit) theologies and conventions and entailed potential conflicts over the maintenance of religious authority (see also Hirschkind 2006). It also became clear that the adoption of modern mass media was less spectacular than the initial puzzlement of scholars that prompted the rise of the new study field of 'religion and media' might suggest. Religious transformations in past and present can fruitfully be analysed by tracing clashes over the use of old and new media (for example, the rejection of devotional images in favour of Bible reading in the post-Lutheran Reformation) in gathering followers and addressing the divine, just as tensions between adherents of different religions can be analysed as conflicts over appropriate uses of media.

The availability and negotiation of media fuels processes of religious transformation, and shapes the ways in which religious groups are positioned in society. While I accept the proposition that religion in modern societies is increasingly mediatised-in that the technologies and formats of mass media and social media become enmeshed with the ways in which religious groups communicate among and about each other and are represented in secular media formats (e.g. Lundby 2018)—I think that the mediatization thesis does not fully explain the complexity of the religion-media nexus (Meyer 2013, 13-15). Here the concept of mediation comes in. Inspired by the work of Hent de Vries (Vries 2001; see also Stolow 2005; Engelke 2010), I came to approach religion as a set of human ideas and practices with regard to another, non-empirical sphere-a beyond-which can only be rendered tangible through mediation, and thus requires some sort of media (see Meyer 2006, 3-14). Discarding a dualism of mass media and religion as each initially belonging to entirely separate spheres (the starting point of, for instance, in Hoover 1997; see also Meyer 2013, 2), this take on mediation entails a broad understanding of media as material means for religious communication among humans and as material harbingers of a professed beyond conventionally referred to as spirits, gods, demons, ghosts, or God. While the mediation of a professed beyond is at the center of how I conceptualize religion (and will form the main focus of this article), I also take into ac-

2 The project involved Marleen de Witte, Ze de Abreu, Francio Guadeloupe, Lotte Hoek, Carly Machado, and Martijn Oosterbaan as PhD-students, and Stephen Hughes, Brian Larkin, Mattijs van de Port, and Rafael Sanchez as postdoctoral researchers. For a joint publication, see Meyer (2009). 
count the use of various media in shaping specific religious identities that are lived by people in the everyday.

Thinking about the religion-media nexus along these lines yielded an approach to religion as implying the use of multiple media that are distinctive for and authorized within particular religious traditions and groups, and need to be acknowledged conceptually and methodologically by scholarship in the study of religion. The entry "Media" in the Käte Hamburger Kolleg (KHK) ${ }^{3}$ working paper series offers a succinct description of the rise of the religion-asmediation approach, and generously quotes my conceptualization of religion "as a practice of mediation between humans and the professed transcendent that necessarily requires specific material media, that is, authorized forms through which the transcendent is being generated and becomes somehow tangible" (Meyer 2013, 8). Importantly, in referring to specific material media as authorized forms, I make two (perhaps so far too implicit) moves, namely 1) from a conventional, everyday notion of media (books, radio, television, internet) to a broader understanding that includes all kinds of stuff-bones, plants, objects-that operate as media in the sense of means and transmitters, and 2) to a broader conceptualization of media as complex authorized, sensational forms employed for the purpose of making connections between the 'here and now' and a 'beyond,' between 'immanent' and 'transcendent.' Sensational forms are complex and composite (second level) media that contain a set of (first level) media but cannot be reduced to them. In my initial launch of the notion of sensational form, I explained the difference between the two levels of media as follows: "Not only do modern media such as print, photography, TV, film, or internet shape sensational forms, the latter themselves are media that mediate, and thus produce, the transcendental and make it sense-able" (Meyer 2006, 14). The question whether and how the adoption and incorporation of certain (first level) media occurs is subject to negotiations that must be examined through detailed research. As sensational forms are produced, authorized, and authenticated within religious traditions and groups, they should not be reduced to the (first level) media which they contain. To analyse the adoption of (first level) media into practices of religious mediation, it is necessary to explore both their technological affordances (in the sense of possibilities for action, Gibson 1966) and the specific ways in which they are framed and deployed. Importantly, I use sensational in an encompassing sense of perception, feeling, and signification, thereby seeking to integrate the role of the senses in sense-making, asking about "den Sinn der Sinne" (Krämer 1998; see also Grieser and Johnston 2017). ${ }^{4}$

Take, for instance, the figure of an angel with a mobile phone on the monumental cathedral Sint Jan in 's-Hertogenbosch in Brabant, in the Catholic southern part of the Netherlands. ${ }^{5}$ Placed on top of the cathedral (at a height of 15 meters) next to other angelic figures in 2011, the angel—called ut Engelke, your little angel—invites phone calls. ${ }^{6}$ Dialling the number listed on the website and on a plaque underneath the angel at the cathedral, one hears a sympathetic, calm male voice, which asks the caller to make a choice in the menu. The first option is to learn more about the angel, who explains that it is a messenger that mediates (bemiddelen) between human beings and God. Angels, one learns, are in principle invisible, and yet present.

3 KHK Working Paper "Media." https://static.ceres.rub.de/media/filer_public/35/0d/350ded7c-8546-41149b39-7a6751f58358/er-khk-4_media_170728.pdf (last accessed September 17, 2019). nomenology in the footsteps of Merleau-Ponty and further deployed by anthropologists of religion as Thomas Csordas, Michael Jackson, and Paul Stoller is not the same as the phenomenology of religion associated with Rudolf Otto (Vásquez 2011, 90-121). 
The little angel says that humans tend to represent and make angels visible through images and sculptures, vesting them with attributes that indicate what they are good at. It also says that it is good at making connections-hence the attribute of the phone. This is an intriguing instance of an uncomplicated, playful use of a new medium such as a mobile phone into an explicit theology of mediation between humans and God. The little angel not only holds a phone and receives phone calls but, by its angelic nature, also claims to mediate divine presence, just as a phone connects people who are at some distance from each other. As an authorized sensational form in the Catholic church, the angel explains itself by drawing an analogy between itself and the phone: it can always be reached by humans and connects them with God.

It is no coincidence that the example of ut engelke fits so well as an illustration of my conceptualization of religion as mediation. This conceptualization is likely to convince when it pertains to religious traditions that explicitly authorize and authenticate certain material forms, such as angelic figures, as harbingers of an extraordinary-divine or spiritual-presence. This pertains not only to Catholicism (Orsi 2012), but also to indigenous religious traditions in Africa, as for example the figure of the legba among the Ewe and Fon, which operates as a guardian of thresholds and a messenger between humans and spirits. Typically, legba figures were understood—and translated—as 'idols' and even demons by the Protestant missionaries active among the Ewe since the mid-nineteenth century. The making of images that incarnate the divine or of figures and objects that mediate between humans and spirits was dismissed as 'idolatry,' and contrasted with a Calvinist-Protestant theology that could do without such material forms (Van Asselt 2007) and harks back to the iconoclasms in the aftermath of the post-Lutheran Reformation (Meyer 2012, 2019a, 88-96). The framework of religion as mediation makes it possible to study clashes between nineteenth-century missionary Christianity and indigenous religious traditions as clashes over the legitimate use and effects of particular sensational forms that are authorized in one tradition and dismissed in another. This is one of the reasons why I was attracted to thinking about religion as mediation in the first place. In my ethnographic and historical work, I tried to show how what missionaries despised as instances of "bad objecthood" (Mitchell 2005) among the Ewe can be framed as viable religious media or sensational forms through which a connection between the 'physical' and the 'spiritual' dimensions of the world, as it is put in Ewe cosmology, is established (Meyer 2015b). My attempt to stress the importance of materiality and media for the study of religion is grounded in this research (Meyer 2012).

However, I argue that religious traditions that explicitly renounce the use of media as harbingers of divinity are not situated beyond mediation. The issue here is that mediation can serve as anchor point of a scholarly meta-language that should be distinguished from emic understandings. In other words, the merit of conceptualizing religion as mediation does not depend on whether interlocutors actually embrace mediation in their own terms. As scholarsand more generally as outsiders-we can spot practices of mediation also where they are unacknowledged or denied (see also Engelke 2007). For example, while Bible reading may be understood as a practice that enables a direct encounter with the word of God by believers, as a scholar I analyze this practice as an instance of the use of Scripture as a medium that is authorized and authenticated as enabling an immediate connection with God; in this sense, Bible reading is a typically Protestant sensational form that is necessarily situated in a specific context, involving the body and senses as well as material culture. The point here is to become aware of the ways in which sensational forms include various (un)acknowledged (first 
level) media, and to consider whether (and to which extent) sensational forms themselves are explicitly framed in terms of mediation by their users. How this occurs is a question to be explored empirically; answering it through comparative study for which mediation serves as a tertium yields important insights into the ways in which religious traditions and groups shape and value mediation and/or tend to emphasize immediacy.

Importantly, mediation does not pertain exclusively to religion, but also to culture and society. Humans relate to each other and the world not in a direct manner, but through particular media that shape how they sense, communicate, and act, and that socially construct reality in a particular way (e.g. Berger and Luckmann 1966; Knoblauch 2017). Many anthropologists approach culture as a practice of mediation (rather than as a fixed and bounded whole). As Johannes Fabian put it succinctly: "Mediated means that experiences (and our understandings) are made, shared, and transmitted by means (lit. things in the middle, media) that include language (in the broadest sense of the term), practices of communication and representation, and material objects. [...] Culture is a discourse on mediations and practices" (2001, 7876; see also Mazzarella 2004; Zito 2008). The media employed are not neutral transmitters of information; paradoxically, they mediate what they transmit into existence ${ }^{7}$ while usually withdrawing from the awareness of their users (Eisenlohr 2011; see also Krämer 2004; Schürmann 2010). Media are not only means but also things in the middle, through which people are able to relate to each other and the world. In principle, media open up multiple possibilities for sharing and communication; which media actually are employed and how they are deployed is subject to both their affordances and power, and necessarily comes at the expense of other possibilities. As authorized media, sensational forms are key to streamline and organize people into communities of sense, or "aesthetic formations" (Meyer 2009).

The recognition of mediality ${ }^{8}$ as a fundamental aspect of relating to, acting in, knowing, understanding, and (re)making the world places the approach to religion as mediation in a wider frame, and by the same token identifies religion as a particularly intriguing domain to study mediation at work. This is so because the importance of bridging between here and a professed beyond is at the core of and explicated in religious practice. This approach can advance our understanding of broader politics and aesthetics of world-making and the mobilization of people via (religious and non-religious) sensational forms through which certain, in the first place abstract, 'entities' - for instance, the people, race, etc.-become real for them. In highly plural societies, in particular, a focus on media and mediation offers a productive entry point into dynamics of diverse and possibly conflicting modes of relating to and (reand un-)making worlds (see the fourth section of this essay).

$7 \quad$ This phrasing intentionally suggests that there is something prior to its transmission via a medium. This 'prior something' usually is not unmediated and raw, but always already conveyed via another medium. This implies the need to approach media and mediation as intersecting and intermedial.

8 For a short introduction to mediality, see "Medialität" in Glossar der Bildphilosophie of Tübingen University: http://www.gib.uni-tuebingen.de/netzwerk/glossar/index.php?title=Medialität (last accessed October 11, 2019). Grounded in ancient Greek philosophy about the mimetic relation between images and reality, mediality pertains to the role of media and mediation in relating to and shaping the world. The term mediality refers not only to a general condition faced by humans in knowing and accessing the world, but also to distinctive features of specific media in doing so. To assess the latter, it is necessary to closely analyze the operation of various kinds of media on the basis of their technological affordances and social modalities of use, examine how they shape perceptions, sensations, and significations for their users, and find out which attitudes and practices they prompt and authorize. 


\section{Critical Interrogations}

Striving to get as close as possible to insiders' views and experiences, some scholars object that what appears as 'media' from the religion-as-mediation perspective digresses too much from how religious practitioners themselves would think about and use media (Hirschkind 2011). In a recent article, Ingie Hovland (2018) argued that taking mediation as a starting point for analysis may stand in the way of grasping the complexity of human-God relations for Protestants who insist on immediate encounters with the divine (as in the case with the Norwegian Lutheran missionaries active in Natal, South Africa she studied). I agree that it would be problematic to employ the concept of religion-as-mediation to prove Protestants wrong about how they understand their practice of relating to God. The points raised by Hovland concern important empirical issues, and I accept that I may have been too eager to unmask a Protestant stance against mediation as a mystification of their own actual practices of mediation. Such unmasking is not the aim of the religion-as-mediation perspective. I find it important to register insider understandings of how (and how not) to link up with the transcendent, and to acknowledge the denial or stated irrelevance of mediation. But doing so on the level of ethnographic research does not imply that mediation must be rejected as a concept. After all, the condition for the tangibility of the transcendent is its mediation, however it occurs. I think that mediation, by directing us toward the sensational forms through which a professed transcendent becomes real for those partaking in them, is a sufficiently open concept to help us grasp insiders' religious ideas and practices, while at the same time facilitating comparison and talking across various religious traditions. In order to do so, some level of abstraction, and a concomitant differentiation between insider and outsider positions, is unavoidable and necessary.

While the conceptualization of religion as mediation may be criticized for hindering a genuine understanding of a particular religious tradition from within, it may also be found to be too close to insider experiences. Having recently moved from anthropology to religious studies, I have noted that many anthropologists, albeit to varying degrees, are inclined towards the first position, and many scholars in religious studies to the second. Driven by the wish to understand cultural Others in their own terms, many anthropologists studying religion wish to 'take religion seriously' and thus tend to be prepared to privilege the categories of their interlocutors above generalizing scholarly formulations. ${ }^{9}$ And they tend to be at greater ease to refer in an uncomplicated emic manner to God, gods, spirits, demons, an otherworld, and a transcendent sphere-entities and realms that are real for their interlocutors-in their writings than scholars in religious studies. Situated in the interface of anthropology and religious studies, the question how to develop a scholarly approach to people's religious experiences in which the transcendent is present and real is a resilient and difficult-to-tackle topic in the study of religion. From the outset, I have emphasized that "my approach to the transcendental is resolutely 'down to earth'" (Meyer 2006, 6) and distinct from a theological (in the sense of believers') perspective. Later on, I replaced "transcendental" with "transcendent," so as to stress that my prime point is to call attention to humans exceeding usual limits (rather than to posit a supernatural entity, which the term transcendental may be understood to denote). In the same vein, I added the adjective "professed" so as to not give the wrong impression that

$9 \quad$ Above all, anthropologists committed to the so-called ontological turn and object-oriented ontologies tend to be prepared to introduce gods, spirits, and God as social actors (for a carefully argued position, see Bialecki 2014). See also Schielke's provocative article about the problem of "avoiding God" in the study of Islam (2019), in which he, as a professed non-believer, points at the limits of methodological atheism. 
I would take the transcendent (let alone God) as my metaphysical starting point. The crux of the matter is not to state that God or spirits are real, but to explore how they become real for practitioners (see also Luhrmann 2004, 2012).

Moving deeper into religious studies, I realized that scholars deal with the issue of the perceived and sensed reality of God and spirits in divergent ways that betray different positions with regard to the aim of their research and the possibility to write about it. I notice a marked difference between scholars (many of them anthropologists) of religion who aim 'to take religion seriously' and therefore refuse to substitute their interlocutors' notion of God and spirits for a scholarly conceptualization and explanation of that notion (for instance, values, or society), and scholars (many of them trained in religious studies) who would venture such explanations with greater ease and confidence, on the other hand. At stake here is a difference in the ways in which emic and scholarly discourses are thought to relate to each other. For the first position, emic discourses are vested with a potential to challenge and compete with scholarly understandings, while the latter draws a stronger boundary between both. ${ }^{10}$ In my own thinking (see Meyer 2016), I seek to take an intermediary position, which I seek to develop through conceptualizing religion as mediation.

Conversations with a number colleagues in religious studies made me realize that an understanding of religion as a practice of mediation between humans and a-professed, imagined, construed-transcendent may trigger suspicions that I might take the existence of the transcendent or divine for granted or confound emic categories and insider experiences with scholarly description and scientific analysis. This remarkable sensitivity and concomitant eagerness of stressing the distance of the scholars from the religious worlds they study may have to do with the fact that, especially in Germany, religious studies had and still has to assert its distinction from theology. The grounding of the discipline in the social and cultural sciences since the 1970s entailed a break from a phenomenology of religion in the footsteps of Rudolf Otto and Mircea Eliade, and a strong conviction that the entities and spheres entailed in the term religion should not be normalized into existence through scholarly discourse.

Having moved from anthropology into religious studies recently, and seeking to reposition my anthropological work therein, I find this stance puzzling and potentially counterproductive. Of course, conceptualizing religion as mediation of a professed transcendent involves a twist in our thinking that accommodates an insider perspective according to which a transcendent sphere does exist, whereas it is not taken to exist outside of that perspective from the standpoint of social-cultural analysis. ${ }^{11}$ For me, making such a twist is not problematic; doing

10 In my (of course, partial) experience, scholars in religious studies appear to grapple, more than anthropologists, with the difference between insider-outsider and emic-etic stances. See the useful special issue by Till Mostowlansky and Andrea Rota (2016) on the debate about these distinctions in the study of religion. From my background in the anthropology of religion, I find a position of methodological ludism (e.g. Knibbe and Droogers 2011) most productive during fieldwork: "It challenges the scholar to adopt, if only for a short period, the believer's way of viewing reality, thereby going beyond the researcher's perspective" (2011, 286). Such a stance yields research materials that must subsequently be transmitted into scholarly writing. While this writing, by definition, is at a distance from how believers view and experience their reality, it should still convey a sense of this reality, and its human and non-human actors, as best and vividly as possible. This has to be achieved through the critical epistemological reflexion that characterizes sound ethnography.

11 In a recent article, Jens Schlieter (2017) criticizes my notion of sensational form (and more generally the material and aesthetic turn in the study of religion) for reinstalling "eine magische Theorie der Bezugnahme" (a magical theory of reference) according to which "Objekte, Dinge, Symbole, oder icons" (objects, things, symbols or icons) are described as communicating by themselves ("als gleichsam selbsttätig kommunizierend") (2017, 205). While he grants that the material and aesthetic turn rightly calls for acknowledging the relevance of physical objects, the body and the senses, he still insists on the primacy of language in 
so is part of anthropological research methods and ways of writing. It is also established as epoché in the study of religion. I share the critique directed at the classical phenomenology of religion (as developed by Otto and Eliade) for positing the existence of God or a transcendent, numinous force that reveals itself to humans and for using epoché as a suspension of judgment in order to grasp and affirm the existence of that force. But this critique does not prevent me from thinking and arguing that the mediation of a professed beyond is at the core of what we call religion (Meyer 2016). ${ }^{12}$ In other words, both in everyday and academic usage, the term religion refers to practices and ideas with regard to a not directly tangible beyond. This layeredness has to be taken into account even though, from a scholarly perspective, that what is understood to be beyond is a human projection or imaginary. As religion thus is a layered rather than 'flat' phenomenon, its study requires continuous, reflexive moves between the views of insiders and outsiders, religious practitioners and scholars. How otherwise can we understand religion as a lived phenomenon? In my view it would be mistaken to strip a scholarly approach to religion to such an extent that its core feature-an orientation towards a professed beyond-is made to disappear (see also Csordas 2004; Meyer 2009, 26-27n13). For me, the intriguing thing about studying religion is that it involves a sense of an unseen reality that is held to exist and yet can only be sensed and rendered present through special techniques. This calls scholars to grasp the ways in which such an unseen reality, a professed transcendent, becomes tangible through practices of mediation, the issue being "how to capture the wow" (Meyer 2016).

making sense about them. In passing, I would like to retort that the concept of sensational form does take the role of language in processes of signification into account (as noted above), but seeks to integrate sensation and signification. This integration concerns a huge theoretical issue of how to synthesize semiotic and phenomenological approaches. I leave this for future deliberation. Here I want to attend to Schlieter's point that my approach to the "Wirkmächtigkeit" (efficacy) of an "icon" rests on an uncritical assumption of its likeness with the object to which it refers. He recognizes that this likeness may be experienced by religious practitioners, but thinks that it should not play any role on the level of analysis. For him, this recognition necessarily requires the mobilization of patterns of interpretation through language, via speech acts. He grants that I, together with my co-authors Kim Knott and Volkhard Krech, state that the efficacy of icons is socially constructed and performatively ascribed. But he still finds that the very process of construction receives too little attention, and is basically taken as "Ausdruck einer Metaphysik der lebendigen Materialität" (an expression of the metaphysics of a living materiality) $(2017,210)$. Schlieter overlooks that in my analysis, in line with insights developed in Bildwissenschaft by a.o. Hans Belting (see below), the likeness evoked by a physical image refers not to an invisible entity out there, but instead to internal images stored in memory and incorporated in a habitus that are activated through seeing a physical image. In this sense, by virtue of acting as media of internal images, external images operate as forms for perception ("Wahrnemungsformen", Belting 2001; Meyer 2015b, 346). In a given religious tradition, people are socialized in a particular visual regime, through which they learn to experience the presence of a professed invisible in a pictorial medium. My point is that the operation of this process involves complex human-image and human-object relations that cannot be understood by a focus on language alone; hence my interest in the material and aesthetic turn and Bildwissenschaft. The dismissal of this approach as magical and metaphysical strikes me not only as a misrepresentation of my work, and the material and aesthetic turn in the study of religion in general, but also as an obvious symptom of the allergy described above.

12 I was stimulated to think along this line through the notion of "awe" as developed by R.R. Marett, who saw religion as grounded in an emotional thrill that arose in moments of crisis, at the point where "thought breaks down" (quoted in Meyer 2016, 14). In distinction to Otto, who based his theory of religion on the existence of a transcendental force that instilled awe, Marett took as a starting-point the human being who is in a state of wonder and amazement, and for whom religion standardizes a 'method' that allows for repeated experiences of awe (which may, of course, be unique and special for individuals, but structured and standardized none the less) (Meyer 2016, 17-18). 


\section{Material Mediations of Transcendence}

In line with the entry "Immanence/Transcendence" in the KHK working paper series, I agree that transcendence should be conceptualized and studied from a material angle in the immanent, as articulated through basic deictic actions of gesturing from 'here' to 'there' that may develop into a "formal transcendence signifying the self-reflective process of 'stepping back and looking beyond' (Schwartz 1975)."13 This conceptualization is far removed from theological or philosophical reflections about the relation between immanence and transcendence as separate categories. From a scholarly angle (and in good Spinozist tradition), the immanent is all there is, and transcendence is understood to operate therein, with religion being the prime arena in which their relation is being articulated. ${ }^{14}$ In this sense, the distinction between immanence and transcendence is part and parcel of speaking about religion as a layered phenomenon, as pointed out above; this requires taking a professed transcendent into account in our research, ${ }^{15}$ and yet not as existent as such on the level of explanation.

Conducive to my anthropological stance, the immanence/transcendence entry takes the practice of transcending as a starting point, and understands transcendence-and the notion of something/a transcendent (or a sublime) - as emanating from this practice. The relation between transcending and transcendence, of course, requires some degree of agreement about how and in which direction to transcend; this agreement is realized and affirmed within a specific regime via authorized sensational forms. Of particular interest for me are the transmitted sets of practices and ideas aimed at 'going beyond the ordinary' and surpassing an experienced-intellectual, emotional, ethical-limit. The experience of a limit, gesturing towards "the rest-of-what-is" (van de Port 2010), and the capacity to transcend in the sense evoked above is, in my understanding, part of being human, indexing a shared humanity. This is where religion thrives: religious traditions offer structured practices for transcending that extend beyond and move across that sense of a limit, be it, as I noticed in my research, in the ways in which spirits are called upon in indigenous Ewe religion or in Pentecostal worship prayers geared to achieve a sense of being filled with the Holy Spirit in Accra. Scholars of religion face the challenge of developing ways to conceptualize these practices without either normalizing what is professed to be beyond the experienced limit as an existing entity (this would imply slipping into religionism), or dismissing it as non-existing (this would imply slipping into atheism). Instead, the sense of limit itself is to form the starting point of our inquiry. This is the backdrop of my interest in the repeated and structured genesis of a sensation of transcendence in the immanent. ${ }^{16}$ As explained, I employ 'sensational form' as a material medium that calls forth a sensation of transcendence in the immanent and via mundane means intrinsic to a religious practice of mediation. The point here is, I want to stress again, not a

13 KHK Working Paper "Immanence/Transcendence”, p. 2. https://static.ceres.rub.de/media/filer_public/3e /33/3e33ee48-f3e4-4eb3-a2e7-259bf6d8abb4/er-khk-7_transcendence_170628.pdf (last accessed September 17, 2019).

14 And thus, in Luhmann's terms, the guiding code of the system of religion is immanence/transcendence. I agree with Kleine (2016) that this code does not only pertain to Christianity, but is applicable to religion in a broad, crosscutting sense.

15 See Bruno Reinhardt (2016) for stressing the importance of paying detailed attention to how Pentecostals in Ghana talk about and enact transcendence. He makes this point so as to criticize a tendency in the approach of religion from a material angle to reduce religion to its sheer materiality and corporeality and, in so doing, to overrule people's own distinctions and practices of transcendence. This point is well taken. In fact, the concept of sensational form is intended to keep the beyond and practices of transcending in the picture.

16 This, of course, may also occur outside of what we conventionally understand as religion, in the sphere of art or advertisements, but also personal encounters in/with 'nature.' 
dualistic take on immanent and transcendent-and related pairs, such as visible-invisible, seen-unseen, tangible-intangible, material-spiritual-but to understand them as interrelated and to ask how the latter is in the former in such a way that the former is experienced to point beyond itself.

Operating within religious traditions and groups to make the presence of spirits, gods, or God real and somehow tangible for (and through) their users, sensational forms are indispensable for a particular experience of transcendence to arise. This is a material and corporeal process. Sensational forms vest material things-natural and human-made-with a sense of a sacred surplus that can be experienced by those taking part in and performing these forms, and even by relative outsiders for whom such material forms may resonate with embodied memories of similar sensational forms in the past. ${ }^{17}$ Such forms, while being physical (and often human-made) objects in the ordinary world, are framed-and likely experienced-as extra-ordinary. Approached and expected to operate as harbingers of the divine, ${ }^{18}$ they are handled with care, and this often involves observing certain restrictions. As noted, the material religious media that herald transcendence and enshrine sacrality do not do so (magically) by themselves, but in the framework of specific religious traditions that authorize and authenticate them as suitable to do so and within which people learn how to do religion, internalizing religious body techniques, developing a religious habitus and opening themselves up to a beyond. How this happens can only be explored through detailed, ethnographic research, and I intend the notion of sensational form as a heuristic device to understand how humans become enveloped in particular practices through which a professed transcendent becomes real for them.

As authorized religious media, sensational forms have a material and corporeal dimension. Buildings, images, objects, food, and texts, for instance, may all feature within sensational forms, and yet entail different material affordances and different corporeal effects and possibilities for signification for their users and beholders. The concept of sensational form is intended as a tool to spotlight structured, authorized, and repeatable formats through which practices of transcending are to be undertaken in religious traditions; these may include prayer, veneration practices, rituals, as well as the use of certain material forms as portals to the beyond. Within a religious tradition, various sensational forms co-exist, overlap with, and enfold each other, while similar sensational forms can be identified across religious traditions. A comparative study of sensational forms that takes seriously their materiality requires expertise-gained through interdisciplinary exchange with the relevant disciplines-about how to study the religious use of, for instance, monumental buildings, devotional images, sacred objects, sacrificial food, and so on, next to texts. This requires an expansion of the traditional text-oriented focus in the study of religion so as to include knowledge regarding, for instance, architecture, art history and visual culture, material culture and archaeology, music, or nutrition, the question being how these material forms impact on and are entangled with their users. This involves a huge task for research that can only be accomplished

17 A case in point is the continued fascination many people (including myself) who do not, or no longer, believe in the Christian God have with visiting churches, sensing some kind of awe vis-à-vis statues and relics, and feeling an urge to light a candle. See Beekers (2016, 2019).

18 In passing, I would like to note that the objects that form the center of sensational forms in other religions may be regarded as harbingers of the demonic, as is the case in, for instance, Ghanaian Pentecostal stances to indigenous religions, which they conceive of and dismiss as pagan and fetishistic (Meyer 2019a). 
collectively (see Grieser and Johnston 2017, and @Koch_Bloomsbury_2019 for a stimulating incentive launched from the aesthetics of religion). ${ }^{19}$

To illustrate how the notion of sensational form can be useful to grasp how transcendence becomes tangible via things and sensations, let me briefly turn to buildings and images. Religious buildings may operate as material media that take part in the social and material construction of reality and, in so doing, are made to point to another realm. In an insightful article on Hindu temples in India and medieval cathedrals in Europe, anthropologist Edmund Leach stated poignantly

Heaven (or hell for that matter) is a negative concept. It is metaphysical and other, the counterpart of the physical here and now. Shrines and temples, however they may be constructed, are 'in reality' physical objects within the confines of this world, but they are also 'the house of God': they belong both to this world and to the other world-they are gateways to heaven (or to hell). And equally, of course, the gateways into temples are gateways into gateways, thresholds of thresholds. (Leach 1983, 251)

Leach's elegant phrasing offers a perfect sense of the operation of a religious building as a material portal opening towards a beyond (besides highlighting the above-mentioned twist which allows combining insider and outsider perspectives). As Joachim Fischer points out in a recent, insightful article on religion and architecture, materiality (even though so far barely thematized in the study of religion) is not a new theme for religion, "but, from a vitalist and anthropological sociological perspective, it creates a constant challenge for every religion, for without materiality religion does not exist: it becomes materially concrete through ritual and physically materializes in houses of worship" $(2017,50) .{ }^{20}$ As "a medium operating according to its own logic of understanding world and self" $(2017,57),{ }^{21}$ a cathedral, temple, or mosque refers to an imaginary transcendent realm beyond-but is at the same time grounded inthe immanent, shapes the built social environment through its permanence, and operates as a 'heavy' medium for social communication. As longstanding material constructions, such buildings constitute (not just symbolize) social differentiations with regard to the sacred and the profane, insiders and outsiders, class, gender, generations, and the living and the dead.

Importantly, the symbolic, spatial-physical, and communicative dimensions of artefacts and buildings are interrelated aspects of materiality through which religion takes place and takes part in constituting society (Karstein and Schmidt-Lux 2017). The power and resilience of material transcendence enshrined in such buildings becomes clearly apparent in times of transition, for instance when a Catholic church is officially withdrawn from service and thus made to lose its authorized sacrality. As pointed out by Daan Beekers, by virtue of its architecture and the remaining hitherto sacred artefacts, such a building still retains a sense of "sacred residue" that echoes its earlier use even in the experience of non-religious or no-morereligious visitors, who may often disapprove the re-purposing or demolition of a church in

19 To further develop such a broad take on religion, I recently launched the research programme Religious Matters in an Entangled World (2016-2024) that studies religion in plural societies from the angle of buildings, images, objects (phase 1), food (phase 2), the body (phase 3) and texts (phase 4). See www.religiousmatters.nl (last accessed September 17, 2019).

20 "...sondern aus einer lebens- und anthroposoziologischen Perspektive bildet es die Dauerherausforderung jeder Religion, ohne die sie nicht ist: ihre materielle Konkretisierung im Ritual und ihre baukörperliche Materialisierung im Gotteshaus" (my translation).

21 „...ein in ihrer 'Materialität' eigenlogisch operierendes Medium der Welt- und Selbsterschließung“ (my translation). 
their neighbourhood (Beekers 2016). ${ }^{22}$ It indexes the continuity of Christian sensibilities in secular Europe, where Christianity is in the process of being reframed as heritage (e.g. Meyer 2019c).

Images are important religious media; they are at the core of devotional practices with their specific "looking acts" that are part of a particular visual regime authorized in a religious tradition, including Protestantism (Morgan 1998). Their status as authorized harbingers of divine presence over and over again has been subject to contestation and triggered charges of idolatry and iconoclastic acts. Operating at the interface of the visible and the invisible, images, as pointed out by Hans Belting (2001), are characterized by a fundamental ambiguity that evolves around the gap between what they represent and the audio-visual codes mobilized for the sake of representation. In other words, a painting or sculpture is a medium that renders present a mental image or figure in the imagination.

Images are of particular interest for the study of religion because they intrinsically involve a referential relation between a physical depiction and something which is not directly visible as such and requires pictorial media to be seen. One could say that the image, by its very 'nature,' has a close affinity with religion, in that both mediate something unseen into some kind of presence. In many religious traditions, images are a key ingredient of sensational forms; their importance is even recognized in their contestation, for instance in the iconoclash undertaken by Calvinist Protestantism (Latour 2002; Meyer 2019a). In his recent work, Belting launched the notion of "iconic presence" to signal the capacity of an image to represent the represented in a pictorial medium (2016). ${ }^{23}$ Iconic presence obviously also pertains to religious images, as they "represent deities who have no direct presence in the physical world; these deities are not held to be absent (let alone non-existent), but in need of a picture in order to become visible" $(2016,235)$. It needs to be stressed that the process of making visible and present is understood as a process that takes place within the image, by virtue of the connection between its external, physical and its internal, mental dimensions, rather than as a magical capacity of images to reveal a 'real' unseen; visibility is not the outcome of an act of making visible something that was hitherto invisible and absent and that is located outside of the physical image that sets out to depict it (see also Geimer 2018). Visibility is relative to the medium through which it occurs, and always partial, rather than throwing full light onto a presumed unseen. Pictorial media streamline and sustain the religious imagination and embodied practices of seeing, which render the professed invisible as visible, the professed absent as present in one way or the other (Meyer 2019b, 4-6, 2019c). Figuring and figuring out a professed transcendent, images form the imagination and shape what and how people see, involving them in practices of viewing and contemplation, without which nothing would be seen at all. Whether, to what extent and how this is realized in a religious tradition is subject to specific negotiations of the role and power to be performed by images; the specificities of the explicit and implicit

22 This research was part of a joint HERA project on Iconic Religion, and of the Religious Matters in an Entangled World research program. For a broad overview of Beekers' research see: https://www.religiousmatters.nl/buildings-images-and-objects/article/converted-churches-mattersof-entanglement-heritage-and-home-1/ (last accessed September 17, 2019).

23 Belting writes that the represented is shown "in and as a picture" (2016, 235). In his writings in English he often observes a distinction between picture and image to refer to the physical, external image and the mental, internal image. Both dimensions are covered in the German term Bild. While I have followed this distinction in my writing for some time, I came to realize that this distinction is potentially confusing because of the dualism enshrined in it. I rather employ the English term 'image' in the conceptual sense of Bild (Meyer, Kruse, and Korte 2018, 10-11). At stake here is not terminology as such, but the importance of making a conceptual differentiation of images as having internal and external dimensions, in the sense that the latter mediates the former. 
image-theologies and habitual use of images can only be identified through detailed research (for a detailed analysis of the role assigned to still and moving images in the Pentecostal visual regime in Ghana and its use of "revelation," see my book Sensational Movies, Meyer 2015b, chap. 4 and 5).

Much more could be said about sensational forms as authorized religious media to render tangible and accessible a professed transcendent and situate it in the world. My point is that taking the media of religion into account alerts us to the fact that a focus on the materiality and corporeality of religion does not reduce it to a 'flat' phenomenon, but instead calls attention to the practices in which the professed transcendent is materialized in the immanent. The issue here is an understanding of the immanent as multi-layered, containing sensations and imaginaries with regard to a beyond. As different religious traditions privilege and authorize various sensational forms as harbingers of transcendence, a focus on the latter offers a productive starting point for the study of conflicts within and between religious traditions, as well as between religious and secular stances, and religious transformations through time.

\section{Coda: Plural Mediations-Mediating Plurality}

Religion comes in the plural. This plurality should be the starting point for our research by default. This perspective is not the same as conceiving of religions-in the plural-as a host of bounded singularities. It certainly makes sense to differentiate between religious traditions and groups and to acknowledge the role of authorized religious media in making for the specificity of each. But the question what makes a tradition or group distinctive should be addressed against the backdrop of "encounters between different religious traditions and concomitant processes of transfer in past and present times"-the stated aim of the Entangled Religions journal. Such encounters are not necessarily equal and innocent, as the nice word 'encounter' may suggest, but are usually shaped within powerful political regimes in which religious difference is negotiated and accommodated. In this context, one has to critically acknowledge the ways in which scholarship contributed to the production of religious difference, for instance through the "world religions" paradigm (Masuzawa 2005) or epistemological complicity in colonial categorizations of religious difference for governance in the frontier zones of imperial outreach (Chidester 1996, 2014).

The term religious plurality does not simply refer to various but in principle equivalent entities grounded in the category of religion. The term itself is already part of attempts of coming to grips with the dazzling plethora of religious forms and elements, and of modes of managing religious difference. And yet, invoking the term plurality—or pluriformity, diversity, or multiplicity ${ }^{24}$-involves fundamental questions of how to grasp actual differences, and the modes through which people live together with and across these differences. How to think

24 I refrain from adding 'pluralism' here due to the strongly normative connotations which the term gained in the politics of its use (see also Beckford 2003, chap. 3; Bochinger 2013). The point for me is to find an adequate term to acknowledge that religion comes in the plural. For now, I prefer the term plurality above diversity (which is too much enmeshed with statecraft), pluriformity (due to is use to legitimate cultural politics sustaining apartheid in South Africa), and multiplicity (due to the fact that the use of this notion tends to imply a neglect of state power in ordering difference). Using plurality as a notion to venture into the study of religious co-existence, it is important to stress that plurality does not assume equal positions of all religious groups and tradition in a society; is subject to state governance and specific ways of regulating religion; and involves relations between and entanglements of religious groups to such an extent that the notion of entities is problematic (for this last point, see Spies 2019). See Meyer (2018, 67, including note 7). 
about, and do research on, religious and other differences without either homogenizing them through the use of equalizing categories or aggrandizing them by claiming radical ontological incommensurability?

Each attempt to study religion across its plural manifestations is historically situated. This undermines, paradoxically, the usefulness of any general conceptualization of religion for a comparative study of plural religious phenomena across time and space that requires such a concept in the first place. But to reject such a general conceptualization is equally problematic. There is no other way than a critical reflexion about the productivity of concepts, theories, and methods for understanding religion in the plural. Taking plurality as default, it may appear counter-intuitive that I advocate conceptualizing religion as mediation. One might object that 'mediation' brushes over-or even homogenizes-differences between religious traditions and groups and the way they are positioned in a political order. As noted in the beginning, I employ mediation as a suitable concept that may be helpful to grasp-or perhaps catch, like a fishing net-certain cross-cutting features as well as factors fuelling tensions and conflict, as well as commensurability and conviviality. Mediation is thus an analytical concept that is itself employed as a medium to spot commonalties and differences.

For me, the question how to grasp the dynamics and plurality of contemporary societies, in which religion is far more resilient than scholars of modernity thought until recently, is one of the biggest empirical and conceptual challenges faced by scholars studying religion. Why and how can the conceptualization of religion as mediation be useful for the study of such dynamics and plural configurations? ${ }^{25}$ One, it can serve as an entry point into the dynamics of missionization, through which certain traditions claim superiority over others, as is the case when Christians or Muslims dismiss African people's intimate relations with spirits as 'idolatry' or 'shirk.' Focusing on mediation is helpful to draw out clashes between competing sensational forms and to trace actual differences between ways of being in and experiencing the world, but also to grasp how sensational forms may mix up, thereby allowing to unpack what may superficially be described as 'syncretism.' Second, a focus on mediation is useful to understand how religious traditions are entangled with each other and share some common ground. This may pertain, for instance, to commonalities between Judaism, Christianity, and Islam, for instance with regard to the fact that they maintain a complicated relation to the use of religious images as harbingers of the unseen (Meyer 2019b).

Third, and most importantly in the context of my current research concerns, a focus on mediation offers a productive conceptual and methodological entry point into the modalities of religious co-existence in various majority-minority configurations in past and present societies. With increasing religious plurality, different sensational forms and the material harbingers of transcendence produced by them exist alongside each other-one mouse click away from each other on the Internet, and close by in urban spaces-and may easily be de-sacralized by ignorant or provocative others. The very act of de-sacralization, of course, requires a recognition of the sacrality enshrined in a particular material item for those who hold it dear. At play is a dialectical move of recognition of something being sacred to someone and its transgression by someone else. Such processes, occurring across the world, as co-existence, and not religious homogeneity, is in fact the default condition which will also hold in the near future-even

25 In the first section of this article, I have addressed the negotiation of newly available secular (mass) media and their incorporation into existing practices of religious mediation. In my earlier work, I tended to focus on mediation so as to analyse the transformations occurring with particular religious traditions. I will not delve into this issue further here, the point being to sketch possibilities for the use of 'mediation' in the study of plurality. 
though scholars may not have realized this in full. While most of my ethnographic work so far relates mainly to Africa, ${ }^{26}$ over the past years I came to find Europe particularly interesting as a location for research. The high intensity of plurality mirrors how global entanglements touch ground in, and colonial relations from the past fold back into, Europe. People with different religious and non-religious convictions and ensuing practices live together in historically situated frames of organizing religion-state relations that echo secular standpoints about the proper place and role of religion in modern societies and tend to take Christianity as a normative model of modern privatized religion against which religious newcomers are measured and valued. To grant freedom of belief is easily compatible with the neutrality of the public sphere and the relative invisibility of religion therein, but to grant freedom of religious expression in a wider, material sense is a different issue altogether, as the many commotions about the material presence of religion-especially-indicate.

While as scholars, we may not want to engage directly in normative debates about the proper place of religions in society, in our research we certainly have to take into account that the manifestation of religion and the right of religious freedom in a modern, secular context is subject to longstanding legal and political regulations. Such regulations organize how different religious groupings are permitted to articulate their presence via material forms, yielding particular regimes for ordering how a religion may be present in a particular society (and how not) (e.g. Burchardt 2017). I think that the concepts of mediation and sensational form can be of use to unpack in detail the stakes behind all kinds of religious matters arising in plural settings. Religion, and religious encounters, certainly cannot be reduced to clashes (and potential overlaps) between sensational forms that materialize transcendence; there also exists a great deal of religious material culture that is distinctive for a particular tradition but does not operate to harbinger a direct link with the divine (such as Muslim dress, or halal food), and through the use of which people mediate their religious identity on a mundane level. But many of the religious matters debated in our time involve sensational forms, for instance with regard to repurposing and recycling hitherto sacred Catholic buildings and images in secular settings (Beekers 2016), building new mosques and sounding the call for prayer (Tamimi Arab 2017), or conflicts about acts and images charged as blasphemic and offensive (Meyer, Kruse, and Korte 2018). It is my hope that the ideas outlined here as to why and how an approach to religion as mediation could be useful as a conceptual and methodological entry point into the dynamics of co-existence and cohabitation in plural configurations may offer fresh possibilities for scholars to mediate religious plurality.

\section{Acknowledgement}

The research on which this article is based has been made possible thanks to the Spinoza award from the Netherlands Foundation for Scientific Research (NWO) and the Academy professor prize from the Royal Netherlands Academy of Arts and Sciences (KNAW). This allowed me to set up the Religious Matters in an Entangled World research programme in the Department of Philosophy and Religious Studies at Utrecht University (www.religiousmatters.nl). Many thanks to Giulia Evolvi and Jessie Pons for inviting me to rework my keynote address at their workshop "Religion, Media and Materiality" (January 2018, CERES) into this text, to

26 In Ghana, I studied conflicts and tensions between mission churches and indigenous priests about the status of vodu or trõ figures dismissed by the former as fetishes and hence as instances of idolatry. This dismissive stance is now reiterated by Pentecostals, who seek to bring about 'a complete break with the past.' 
Pooyan Tamimi Arab, Bruno Reinhardt and two anonymous reviewers for detailed, engaging and to some extent divergent comments on earlier versions, and to Julia Heinig and Maren Freudenberg for copy editing and language corrections. I dedicate this piece to Jojada Verrips, with heartfelt thanks for his pertinent and sharp questions in our ongoing discussions about the possibility to approach religion as mediation. All shortcomings are mine.

\section{References}

Anderson, Benedict R. 1991. Imagined Communities: Reflections on the Origin and Spread of Nationalism. London: Verso.

Asad, Talal. 1993. Genealogies of Religion: Discipline and Reasons of Power in Christianity and Islam. Baltimore: Johns Hopkins University Press.

Beckford, James A. 2003. Social Theory and Religion. Cambridge: Cambridge University Press. Beekers, Daan. 2016. "Sakrale Residuen/Sacred Residue." In The Urban Sacred-Städtischreligiöse Arrangements in Amsterdam, Berlin und London / How Religion Makes and Takes Place in Amsterdam, Berlin and London. Ausstellungskatalog/Exhibition Catalogue, edited by Susanne Lanwerd, 36-41. Berlin: Metropol.

- 2019. "The Matter of Home: Church Repurposing, Memory and Belonging in Amsterdam." presented at the Presentation Conference Religion and Heritage, Groningen, June $19-21$.

Belting, Hans. 2001. Bild-Anthropologie: Entwürfe für eine Bildwissenschaft. München: Fink Verlag.

— 2016. "Iconic Presence. Images in Religious Traditions." Material Religion 12 (2): 23537. https://doi.org/10.1080/17432200.2016.1172769.

Berger, Peter L., and Thomas Luckmann. 1966. The Social Construction of Reality; A Treatise in the Sociology of Knowledge. Garden City, N.Y.: Doubleday.

Bialecki, Jon. 2014. "Does God Exist in Methodological Atheism? On Tanya Luhrmann's When God Talks Back and Bruno Latour." Anthropology of Consciousness 25 (1): 32-52.

Bochinger, Christoph. 2013. "Ist religiöse Vielfalt etwas Gutes? Pluralismus und Pluralität in der Religionswissneschaft." In Alternative Voices. A Plurality Approach for Religious Studies. Essays in Honor of Ulrich Berner, edited by A. Adogame, M. Echtler, and O. Freiberger, 285-307. Göttingen: Vandenhock \& Ruprecht.

Burchardt, Marian. 2017. "Infrastrukturen des Religiösen: Materialität und urbane Ordnungsregime." In Architekturen und Artefakte. Zur Materialität des Religiösen, edited by Uta Karstein and Thomas Schmidt-Lux, 233-50. Wiesbaden: Springer.

Chidester, David. 1996. Savage Systems: Colonialism and Comparative Religion in Southern Africa. Charlottesville: University Press of Virginia.

- 2014. Empire of Religion: Imperialism and Comparative Religion. University Of Chicago Press.

- 2018. Religion: Material Dynamics. Oakland: University of California Press.

Comaroff, Jean, and John Comaroff. 1992. Of Revelation and Revolution: Christianity, Colonialism, and Consciousness in South Africa. Vol. 1. Chicago and London: University of Chicago Press.

1997. Of Revelation and Revolution: The Dialectics of Modernity on a South African Frontier. Vol. 2. Chicago and London: University of Chicago Press. 
Csordas, Thomas J. 2004. "Asymptote of the Ineffable: Embodiment, Alterity, and the Theory of Religion." Current Anthropology 45 (2): 163-86.

Dubuisson, Daniel. 2003. The Western Construction of Religion: Myths, Knowledge, and Ideology. Baltimore, Md: The Johns Hopkins University Press.

Eisenlohr, Patrick. 2011. "The Anthropology of Media and the Question of Ethnic and Religious Pluralism." What Is a Medium? Social Anthropology 19 (1): 40-55.

Engelke, Matthew. 2007. A Problem of Presence: Beyond Scripture in an African Church. Berkeley: University of California Press.

—. 2010. "Religion and the Media Turn: A Review Essay." American Ethnologist 37 (2): 371-79.

Esser, Raingard. 2018. "Contested Space in a Contested Border Area: The Sint Jan in 's Hertogenbosch - Or: From Bosch to the Ten Commandments." Entangled Religions 7: 46-77. https://doi.org/10.13154/er.v7.2018.46-77.

Fabian, Johannes. 2001. "Interpretation in Anthropology." In International Encyclopedia of the Social \& Behavioral Sciences, edited by N. J. Smelser and P. B. Baltes, 7874-8. Amsterdam: Elsevier.

Fischer, Joachim. 2017. "Gebaute Welt als schweres Kommunikationsmedium der Gesellschaft. Architektur und Religion aus architekturhistorischer Perspektive." In Architekturen und Artefakte. Zur Materialität des Religiösen, edited by Uta Karstein and Thomas Schmidt-Lux, 49-69. Wiesbaden: Springer.

Geimer, Peter. 2018. Inadvertent Images: A History of Photographic Apparitions. Chicago, IL and London: The University of Chicago Press.

Gibson, James G. 1966. The Senses Considered as Perceptual Systems. London: Allen \& Unwinn.

Grieser, Alexandra K., and Jay Johnston, eds. 2017. Aesthetics of Religion A Connective Concept. Berlin: Walter de Gruyter.

Hermann, Adrian. 2015. Unterscheidungen der Religion: Analysen zum globalen Religionsdiskurs und zum Problem der Differenzierung von „Religion“ in buddhistischen Kontexten des 19. und frühen 20. Jahrhunderts. Göttingen: Vandenhoeck \& Ruprecht.

Hirschkind, Charles. 2006. The Ethical Soundscape: Cassette Sermons and Islamic Counterpublics. New York: Columbia University Press.

—. 2011. "Media, Mediation, Religion." Social Anthropology 19 (1): 90-97.

Hoover, Stewart M., and Knut Lundby, eds. 1997. Rethinking Media, Religion and Culture. London: Sage.

Hovland, Ingie. 2018. "Beyond Mediation: An Anthropological Understanding of the Relationship Between Humans, Materiality, and Transcendence in Protestant Christianity." Journal of the American Academy of Religion 86 (2): 425-53.

Karstein, Uta, and Thomas Schmidt-Lux, eds. 2017. Architekturen und Artefakte. Zur Materialität des Religiösen. Wiesbaden: Springer.

Keane, Webb. 2007. Christian Moderns: Freedom and Fetish in the Mission Encounter. Oakland: University of California Press.

Kippenberg, Hans G. 1997. Die Entdeckung der Religionsgeschichte. Religionswissenschaft und Moderne. München: C. H. Beck.

Kleine, Christoph. 2016. "Niklas Luhmann und die Religionswissenschaft: Geht das zusammen?" Zeitschrift für Religionswissenschaft 24 (1): 47-82.

Knibbe, Kim, and André Droogers. 2011. "Methodological Ludism and the Academic Study of Religion." Method and Theory in the Study of Religion 23: 283-303. 
Knoblauch, Hubert. 2017. Die kommunikative Konstruktion der Wirklichkeit. Wiesbaden: Springer.

Koch, Anne, and Katharina Wilkens, eds. 2019. The Bloomsbury Handbook of Cultural and Cognitive Aesthetics of Religion. London ; New York: Bloomsbury Academic.

Krämer, Sybille. 1998. "Sinnlichkeit, Denken, Medien: Von der 'Sinnlichkeit als Erkenntnis' zur 'Sinnlichkeit als Performanz'." In Der Sinn der Sinne, edited by B. Busch, A. Müller, and J. Seligmann, 24-39. Göttingen: Steidl.

- 2004. Performativität und Medialität. München: Fink.

Latour, Bruno. 2002. "What Is Iconoclash? Or Is There a World Beyond the Image Wars?" In Iconoclash, edited by Peter Weibel, 14-18. Karlsruhe, Cambridge: ZKM , MIT Press.

Leach, Edmund Ronald. 1983. "The Gatekeepers of Heaven: Anthropological Aspects of Grandiose Architecture." Journal of Anthropological Research 39: 243-64.

Luhrmann, Tanya M. 2004. "Metakinesis: How God Becomes Intimate in Contemporary U.S. Christianity." American Anthropologist 106 (3): 518-28.

- 2012. When God Talks Back: Understanding the American Evangelical Relationship with God. New York: Alfred A. Knopf.

Lundby, Knut, ed. 2018. Contesting Religion: The Media Dynamics of Cultural Conflicts in Scandinavia. Berlin: De Gruyter. https://www.degruyter.com/viewbooktoc/product/478981.

Masuzawa, Tomoko. 2005. The Invention of World Religions, or, How European Universalism Was Preserved in the Language of Pluralism. Chicago: University Of Chicago Press.

Mazzarella, William. 2004. "Culture, Globalization, Mediation." Annual Review of Anthropology 33: 345-67.

Meyer, Birgit. 2009. "Introduction: From Imagined Communities to Aesthetic Formations: Religious Mediations, Sensational Forms and Styles of Binding." In Aesthetic Formations: Media, Religion, and the Senses, edited by Birgit Meyer, 1-28. Basingstoke: Palgrave Macmillan.

— 2013. "Material Mediations and Religious Practices of World-Making." In Religion Across Media: From Early Antiquity to Late Modernity, edited by Knut Lundby, 1-19. New York: Peter Lang.

- 2015a. "Picturing the Invisible. Visual Culture and the Study of Religion." Method and Theory in the Study of Religion 27: 333-60.

- 2015b. Sensational Movies. Video, Vision and Christianity in Ghana. Berkeley: The University of California Press.

— 2016. "How to Capture the 'Wow': R.R. Marett's Notion of Awe and the Study of Religion." Journal of the Royal Anthropological Institute 22. https://doi.org/10.1111/14 67-9655.12331.

- 2018. "Frontier Zones and the Study of Religion." Journal for the Study of Religion 31 (2): 57-78. https://doi.org/10.17159/2413-3027/2018/v31n2a3.

— 2019a. "Idolatry Beyond the Second Commandment. Conflicting Figurations and Sensations of the Unseen." In Figurations and Sensations of the Unseen in Judaism, Christianity and Islam, edited by Terje Stordalen and Birgit Meyer, 77-96. London: Bloomsbury. http://dx.doi.org/10.5040/9781350078666.0011.

—. 2019b. "Introduction: Figurations and Sensations of the Unseen in Judaism, Christianity and Islam." In Figurations and Sensations of the Unseen in Judaism, Christianity and Islam, edited by Terje Stordalen and Birgit Meyer, 1-18. London: Bloomsbury. http://dx.doi.org/10.5040/9781350078666.0006. 
. 2019c. "Recycling the Christian Past. The Heritagization of Christianity and National Identity in the Netherlands." In Culture, Citizenship and Human Rights, edited by Rosemarie Buikema, Antoine Buyse, and Antonius Robben. London and New York: Routledge.

- 2006. "Religious Sensations. Why Media, Aesthetics and Power Matter in the Study of Contemporary Religion." Inaugural Lecture, Vrije Universiteit, Amsterdam, October 6. https://research.vu.nl/en/publications/religious-sensations-why-media-aestheti cs-and-power-matter-in-the- 2 .

- 2012. "Mediation and the Genesis of Presence. Towards a Material Approach to Religion." presented at the Inaugural Lecture, Utrecht University, October 19. https: //www.uu.nl/file/25377/download?token=bVR2qMgL.

Meyer, Birgit, Christine Kruse, and Anne-Marie Korte. 2018. "Introduction." In Taking Offense: Religion, Art, and Visual Culture in Plural Configurations, edited by Christine Kruse, AnneMarie Korte, and Birgit Meyer, 7-14. München: Fink. https://doi.org/10.30965/97838 46763452 003.

Mitchell, W. J. Thomas. 2005. What Do Pictures Want? The Lives and Loves of Images. Chicago: University Of Chicago Press.

Morgan, David. 1998. Visual Piety: A History and Theory of Popular Religious Images. Berkeley: University of California Press.

Mostowlansky, Till, and Andrea Rota. 2016. "A Matter of Perspective? Disentangling the Emic-Etic Debate in the Scientific Study of Religion|s." Method \& Theory in the Study of Religion 28 (4/5): 317-36.

Orsi, Robert. 2012. "Material Children: Making God's Presence Real Through Catholic Boys and Girls." In Religion, Media and Culture: A Reader, edited by Gordon Lynch, Jolyon P. Mitchell, and Strhan, 147-58. London: Routledge.

Port, Mattijs van de. 2010. Dat wat rest...: over sacralisering en de ongerijmdheden van het bestaan. Amsterdam: Vrije Universiteit. https://research.vu.nl/en/publications/dat-wat-rest-ov er-sacralisering-en-de-ongerijmdheden-van-het-best.

Reinhardt, Bruno. 2016. “'Don't Make It a Doctrine': Material Religion, Transcendence, Critique." Anthropological Theory 16 (1): 75-97.

Schielke, Samuli. 2019. The Power of God. Four Proposals for an Anthropological Engagement. Vol. 13. Programmatic Texts. Berlin: Leibniz-Zentrum Moderner Orient. https://d-nb.i nfo/1175974781/34.

Schlieter, Jens. 2017. "Religiöse Symbole im öffentlichen Raum: Symbolwirkung als kollektive Intentionalität einer Deutungsgemeinschaft." Zeitschrift für Religionswissenschaft 25 (2): 196-232.

Schürmann, Eva. 2010. "Die Medialität von Medien." In Raum-Perspektive-Medium 2: Wahrnehmung Im Blick, edited by Yvonne Schweizer, Anna Quintus, Barbara Lange, Julica Hiller-Norouzi, and Philipp Freytag. Tübingen. https://publikationen.unituebingen.de/xmlui/handle/10900/46566.

Spies, Eva. 2019. "Being in Relation: A Critical Appraisal of Diversity and Mission Encounter in Madagascar." Journal of African Religions 7 (1): 62-83.

Stausberg, Michael. 2012. "Religion: Begriff, Definitionen, Theorien." In Religionswissenschaft, 33-47. Berlin: Walter de Gruyter.

Stolow, Jeremy. 2005. "Religion and/as Media." Theory, Culture \& Society 22 (4): 119-45. 
Tamimi Arab, Pooyan. 2017. Amplifying Islam in the European Soundscape: Religious Pluralism and Secularism in the Netherlands. London: Bloomsbury. http://dx.doi.org/10.5040/978 1474291460.

Van Asselt, W. J. 2007. "The Prohibition of Images and Protestant Identity." In Iconoclams and Iconoclash. Struggle for Religious Identity, edited by P. van Geest, D. Müller, and T. Salemink, 299-311. Leiden: Brill.

Vásquez, Manuel A. 2011. More Than Belief. A Materialist Theory of Religion. New York: Oxford University Press.

Vries, Hent de. 2001. "In Media Res: Global Religion, Public Spheres, and the Task of Contemporary Religious Studies." In Religion and Media, edited by Samuel Weber, 4-42. Stanford: Stanford University Press.

—. 2008. "Introduction: Why Still 'Religion'?" In Religion: Beyond a Concept, 1-98. New York: Fordham University Press.

Wittgenstein, Ludwig. 2001. Philosphische Untersuchungen. Philosophical Investigations. The German Text, with a revised German Translation. Translated by G. E. M. Anscombe. Malden, Oxford: Blackwell.

Zito, Angela. 2008. "Culture." In Key Words in Religion, Media and Culture, edited by David Morgan, 69-82. New York: Routledge. 